\title{
El fracaso o la anti épica en dos novelas venezolanas contemporáneas: El pasajero de Truman y Sumario
}

Celso Medina

(2) OpenEdition Journals

Edición electrónica

URL: https://journals.openedition.org/cher/12099

DOI: 10.4000/cher.12099

ISSN: 2803-5992

Editor

Presses universitaires de Strasbourg

Edición impresa

Fecha de publicación: 30 junio 2012

Paginación: 63-74

ISBN: 978-2-35410-046-9

ISSN: 1968-035X

Referencia electrónica

Celso Medina, «El fracaso o la anti épica en dos novelas venezolanas contemporáneas: El pasajero de Truman y Sumario», reCHERches [En línea], 8 | 2012, Publicado el 21 febrero 2022, consultado el 23 febrero 2022. URL: http://journals.openedition.org/cher/12099 ; DOI: https://doi.org/10.4000/cher. 12099

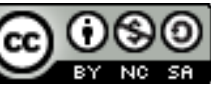

Ce(tte) œuvre est mise à disposition selon les termes de la Licence Creative Commons Attribution -

Pas d'Utilisation Commerciale - Partage dans les Mêmes Conditions 4.0 International. 


\title{
El fracaso o la anti épica en dos novelas venezolanas contemporáneas: El pasajero de Truman y Sumario
}

\author{
Celso Medina \\ Universidad Pedagógica Experimental Libertador \\ Instituto Pedagógico de Maturín
}

... el hombre es el animal a quien esencialmente le corresponde la posibilidad de caer José Luis Pardo

\begin{abstract}
T a novela y el ensayo son los grandes géneros que en Venezuela han Lhecho patente la idea del fracaso. Decíamos en otra oportunidad (Medina 2006) que la novelística venezolana de los siglos XIX y XX se amparó en concepciones sociopolíticas, en especial las del positivismo y las del vitalismo nietzcheano, reduciendo su «mirada a la de un ojo crítico, más pendiente de las ideas que de la estética» (751). Dos novelas las emblematizan: Peonía (1890) e Ídolos Rotos (1901). Las mismas están facturadas desde el pesimismo. Sus dos protagonistas, Carlos y Alberto Soria, flanqueados en sus visiones liberales y vitalistas, escenifican el fracaso del individuo ante una sociedad negada a la modernización de la ciencia y de las artes.

En lo que concierne al ensayo, podemos decir que con él los intelectuales venezolanos se dedicaron especialmente a diagnosticar la sociedad venezolana, ofreciendo, desde sus diversas tendencias, la imagen de una Venezuela destinada al fracaso. Dos textos son representantes de esas visiones: Cesarismo democrático, de Laureano Vallenilla Lanz (1919) y Mensaje sin destino (1951), de Mario Briceño Irragory. Desde el positivismo y desde un humanismo de tendencia existencial, estos autores muestran
\end{abstract}


cómo las utopías independentistas fracasan ante una historia nacional caracterizada por una alta tendencia entrópica. Pero en esta oportunidad vamos a ocuparnos de la novela venezolana como género que pulsa ese sentimiento de fracaso. Y lo haremos a partir de la lectura de dos novelas novísimas, que reactualizan ese tema.

No es gratuito el uso de la novela como instrumento para patentizar el fracaso. Este género en sí mismo nace amparado en el clima de pesimismo que originó la sociedad moderna. Valiéndonos de la imagen de José Luis Pardo, diríamos que la novela es el relato de un equilibrista, conjurando su caída. Y es a la vez la narración del héroe caído, del hombre "degradado, actuando en un medio degradado", para decirlo en frases de Lucien Goldmand. Por ello, disentimos de Lukács cuando afirma que la génesis de la novela es la epopeya; creemos más bien que es la tragedia su origen. Sólo que su fatum agudiza su impronta trágica cuando se entrevera con elementos de la comedia, haciendo de la risa un rictus que esconde la amarga vida del héroe caído.

En Venezuela la novela nace en 1842 con Los Mártires de Fermín Toro. La militancia de su autor en el Socialismo Utópico inglés hace que su novela tenga el sello del pesimismo. Sus héroes son aplastados por la crisis social que caracterizaba la Inglaterra de los años 30, espacio histórico donde interactúan los personajes torianos. El pionero de la novelística venezolana prefirió escribir sobre una exótica realidad. Pero pensamos que no lo hizo con un afán escapista. Al describir un ambiente europeo plagado de injusticias, parecía estar advirtiendo que la propuesta política para Venezuela debería distanciarse de aquel ambiente.

Ese sentimiento de naufragio se intensifica en Venezuela con el nacimiento de su novela histórica. Ella acentúa esa lucha por los protagonismos de los personajes fracasados. Introduce en nuestra literatura una compleja aporía. La ficción se deja conquistar por la historiografía, problematizando la relación de las "entidades históricas" con las "entidades anónimas". Para Paul Ricœur: «El historiador se dirige a un lector desconfiado que espera de él no sólo que narre, sino que también autentifique su narración» (297). El lector de la historia aspira a lo plausible, cuya verosimilitud le dé certezas. Aspiración que falla, cuando surge la Novela Histórica como género. Lukács la definió como «representación artísticamente fiel de un período histórico concreto» (89). Concepto que lleva en sí su aporía: «artísticamente fiel» es una frase que construye un oxímoron. ¿Cómo puede ser fiel el arte a la realidad, sin traicionar su propensión a lo imaginario? Ese género surge del 
fracaso de la historia; su hermenéutica falla en el campo de la historiografía, y se ve obligada a invadir el campo de la ficcionalidad, para, a través de los imaginarios, explicitar sus verdades.

Uno de los novelistas venezolanos más avanzados de nuestra vanguardia, Arturo Uslar Pietri, escribe una novela histórica para hacer patente esa tendencia pesimista de nuestra novelística: Las lanzas coloradas (1931), en la que se ofrece lo que pudiéramos calificar como la clara anti épica de la lucha proindependentista venezolana. Pero donde viene a adquirir más profundidad esa idea de fracaso es en la novela política venezolana. Según Irwing Howe este género nace:

Para hacer que las ideas e ideologías cobren vida, para dotarlas con la capacidad de agitar a los personajes dentro de gestas apasionadas y sacrificios, e incluso más, para crear la ilusión de que tienen una especie de movimiento independiente, de manera que los mismos -esos derechos abstractos o ideas o ideologías- parezcan convertirse en personajes activos... (34).

En el caso de Venezuela, la Novela Política, tendencia en la que ubicamos las obras que vamos a analizar aquí, convierte a los protagonistas históricos en personajes, los dota de caracteres, los desaloja de su ámbito público, arrojándolos en un espacio donde las "razones de Estado" se supeditan al famoso síndrome de La Nariz de Cleopatra. Recordemos lo que Blaise Pascal nos dice sobre ese síndrome: «Si Cleopatra hubiera tenido una nariz más corta hubiera cambiado la faz del mundo». Ese determinismo configura la trama, pues toda la acción depende de las peripecias del hombre de Estado, sobre quien pesa la responsabilidad de cambiar o mantener «la faz del mundo». Es la acción de él lo que hace que «las ideas o las ideologías cobren vida». Pero el político es un hombre, a quién «le corresponde la posibilidad de caer», siguiendo a Pardo.

La novela venezolana vive actualmente un revival de lo histórico. Su retorno al pasado aparece en medio de un clima político donde la historia se ha hiperideologizado. Algunos críticos han destacado cierto utilitarismo en esta tendencia. Al respecto afirma Juan Carlos Santaella, en una entrevista ofrecida a Daniel Centeno:

Ocurre que muchas personas ven en la novela histórica una vía de aprendizaje académico. Es decir, creen que están leyendo grandes verdades en estos libros. Olvidan que los escritores mienten y que no saben nada de historia ni de filosofía ni de política (28).

Parte del hecho de que sólo la historia, la filosofía y la politología pueden hablar de "grandes verdades"; por ello tilda a los novelistas que acuden 
al género de mentirosos, afirmándose en un dogma: el escritor sólo debe ficcionalizar. En cambio, una escritora practicante de la novela histórica, Ana Teresa Torres afirma: «es la historia una suerte de ancla, de sentimiento de que hay algo a la que aferrarse» (28). Esa ancla parece ser el instrumento al que algunos narradores venezolanos contemporáneos acuden para auscultar el presente venezolano.

Venezuela a partir de la llamada era chavista (desde 1999 o tal vez a partir del intento de golpe que comandó Hugo Chávez en 1992) vive una intensa experiencia con el ejercicio de la política. Se puede decir que como nunca esta actividad se ha democratizado. $\mathrm{Y}$ esa politización ha tenido un alto componente historicista. Para los afectos al presidente Chávez, en el pasado hay importantes iconos que sirven de modelo a lo que llaman la Revolución Bolivariana. El más importante de ellos es Simón Bolívar, el Libertador. A su alrededor se ha puesto a girar un panteón de héroes (Miranda, Sucre, Zamora, etc.) reconstituyendo la práctica ideologista de la historia romántica, impulsora de la Historia Patria.

Los opositores al presidente Chávez han tejido, por su parte, una trama historicista que ha abandonado la historiografía general de Venezuela, indagando en lo íntimo los personajes históricos, procurando restarles la majestuosidad a sus heroísmos. Bajado de su mármol, los héroes se truecan en verdaderos elementos que sirven para desarrollar el símil del pasadopresente. Por ello hace uso de una tradición genérica: la novela histórica política. Se arma un símil: el presente es como el pasado. Y ante la impotencia de vencer el presente, se le asesta un duro golpe a lo pretérito. Reviviendo algunos tópicos del ensayo positivista venezolano, la novelística escrita por escritores afectos a esta posición política se ha sustentado en una narrativa de tesis, que sostiene que en virtud de que Venezuela es actualmente víctima del militarismo, hay que reavivar el civilismo.

Federico Vegas y Francisco Suniaga son escritores con una explícita tendencia antichavista, que se expresa en sus declaraciones de prensa, en la firma de algunos manifiestos, etc. Son ellos los autores de las novelas que estudiaremos aquí, para hacer patente la idea contemporánea del fracaso en la literatura venezolana. Diógenes Escalante y Carlos Delgado Chalbaud son dos políticos importantes del siglo $\mathrm{XX}$ que protagonizan las novelas de Suniaga (El Pasajero de Truman, 2008) y Vegas (Sumario, 2010) que conforman un interesante boom de la novela histórica política que hoy hace su aparición en la historiografía literaria venezolana. En ellas podemos percibir el desarrollo de un símil ¿Cuáles son sus elementos? Por supuesto, uno es el presente (sutilmente elidido) y el otro es la coyuntura política que 
va de la muerte del dictador Juan Vicente Gómez, quien gobernó al país desde 1908 a 1935, al magnicidio de Carlos Delgado Chalbaud (en 1950).

La década que sigue a la muerte del dictador Juan Vicente Gómez generó una enorme expectativa. El país venía de haber sufrido una cruenta dictadura que duró 27 años. Por ello su desaparición hizo que irrumpiera en el espacio público una abundante discusión acerca del destino de Venezuela. Nacieron los partidos políticos contemporáneos y la política se ejerció con una inusitada libertad. Pero el Gomecismo no desapareció abruptamente; pasó por un proceso que poco a poco intentaba servir de transición a gobiernos completamente civiles, lo que no pudo cumplirse sino el año 1958, cuando, caída la última dictadura venezolana (la de Marcos Pérez Jiménez) se eligió presidente a un civil, Rómulo Betancourt. El experimento democrático de Rómulo Gallegos fue efímero: fue el primer presidente electo por voto secreto y universal (febrero de 1947), se encargó del gobierno en febrero de 1948 y en noviembre del mismo año fue depuesto.

Varias figuras y varios eventos fueron forjando ese camino. Dos de ellas fueron Diógenes Escalante y Carlos Delgado Chalbaud; el primero civil, el segundo militar. En ellos estuvo centrado el interés de la política venezolana. Pero ambos desaparecieron de esa escena de manera intempestiva: uno enloqueció, en víspera de convertirse en el primer presidente civil del siglo $\mathrm{XX}$; el otro fue asesinado en un complot que aún la historiografía no ha podido dilucidar. Estos personajes son objeto de ficcionalización por parte de los dos novelistas venezolanos ya nombrados. Ambos dan cuenta de cómo esa expectativa concluyó en un estridente fracaso. Fracaso que sirve de elemento del símil pasado-presente en las novelas de Vegas y Suniaga.

La concepción de la novela histórica que manejan ambos autores parece distanciarse de la tradición del género. Para éste «Los vacíos historiográficos son su punto de partida. Completarlos es su trabajo» (Medina 2005: 14). Esas novelas se alejan de los «realemas» (Even-zohar 1980). Ni la historia ni los personajes son «unidades mínimas de realidad». La realidad historiográfica es presentada en forma prolija. Abundan los datos, el registro de eventos; pero no es el deseo de llenar «vacíos historiográficos», lo que mueve a estos escritores, sino una especie de bulimia historicista; un hartazgo de datos que derivará en un gran fracaso: en una hermenéutica fallida, donde la historia termina oscureciéndose. No en vano, en ambas novelas la principal acción diegética es la búsqueda. Un periodista quiere completar el affaire histórico de Diógenes Escalante; y un escribiente secretario quiere aclarar las oscuridades del juicio contra el asesino de Carlos Delgado Chalbaud, 
Rafael Urbina. Aquí se devela el primer fracaso: la historia es un fenómeno condenado a la inefabilidad. De ella se pueden derivar moralejas, mas no verdades.

En El Pasajero de Truman Francisco Suniaga teje su trama a partir del encuentro de Román Velandia y Humberto Ordoñez; el primero periodistahistoriador, el segundo diplomático, secretario privado de Diógenes Escalante, embajador de Venezuela en Estados Unidos y candidato del entonces presidente de Venezuela, Isaías Medina Angarita a sustituirlo. A pesar de que sus nombres son ficticios, al final de la novela el autor anota: «quería expresar mi más profunda gratitud a Ramón J. Velásquez y Hugo Orozco» (los personajes reales que estuvieron muy cerca a Diógenes Escalante, en la hora de su desgracia).

La novela se ocupa de desandar, sesenta años después de los hechos, el hilo de lo sucedido «cuando ambos trabajaron juntos durante la semana al lado del hombre que vino a salvar a la patria y no pudo» (2008: 9). Velandia tiene noventa años y su interlocutor ochenta. Éste se ayuda «con un bastón que parecía una pieza imprescindible para su equilibrio» (13). Velandia es periodista (historiador de lo presente) e historiador (historiador de lo pasado), testigo y participante de la desgracia que se erigiera sobre el infausto Diógenes Escalante. Está convencido de que: «Es necesario que usted y yo, que fuimos parte de la peripecia más infortunada vivida por Venezuela en el siglo XX, aclaremos algunas cuestiones oscuras en esta historia» (16).

Leemos, pues, el desandar de una historia en la que habrá una rica polifonía: la voz de los dos que dialogan en la casa del ex-secretario del político infortunado, la de los recuerdos del Dr. Escalante, y las voces que éste activa cuando rememora su vida familiar y sus avatares políticos, al lado de los presidentes de Venezuela Cipriano Castro, Juan Vicente Gómez, Eleazar López Contreras y Medina Angarita. Todo gira alrededor de las últimas tres semanas que permaneció en Venezuela Escalante antes de que enloqueciera, y en «el viaje de regreso a Washington, derrotado, en su interminable camino hacia el olvido» (19).

La novela construye un Sísifo criollo: un ser con ambición, pero resignado. Por tres veces estuvo a punto de ser presidente del país: con Gómez, con Eleazar López Contreras y con Isaías Medina Angarita. Este último, para procurar cambiar la tradición de los presidentes militares, le ofrece que deje la embajada en Estados Unidos y asuma la candidatura a presidente, posición a la que accedería sin problemas, porque el Congreso, a quien le tocaba elegirlo, estaba en manos del entonces presidente. Esa 
propuesta la medita; la consulta con su familia, con los voceros de la política contemporánea más calificada. La novela nos muestra a un personaje conflictuado, casi abúlico. De boca de Ordóñez, oímos esto: «debió escuchar muchas veces la ironía de que vinieran a ofrecerle la posición que más quiso cuando ya no podía quererla» (18). Cuando parece que va a detener la eterna piedra (su deseo de ser presidente), enloquece.

En algunas oportunidades el autor parece deslizarse en las palabras del personaje central. Resulta históricamente poco verosímil pensar en Diógenes Escalante como un hombre de grandes ideas democráticas. Sobre todo si tomamos en cuenta que fue funcionario privilegiado de los dictadores Castro y Gómez, y que en el postgomecismo le tocó asumir un ministerio importante, el de Relaciones Interiores, y que ocupó las embajadas más emblemáticas de la diplomacia venezolana, como son las de Estados Unidos e Inglaterra. El narrador pone en boca de Escalante sus planes:

Ese es uno de los planes que me propongo ejecutar si acepto la Presidencia, disponer de la renta petrolera para crear una clase empresarial fuerte, entrenada en hacer negocios y dispuesta a generar riqueza [...] el problema de un gobernante no es que haya ricos, sino que haya pobres. [...] Lo que ha existido es una renta petrolera que está allí por un accidente geológico y que el Estado administra (118).

Ideas éstas que salen más de la intrautoría, que de la misma diégesis. El narrador no es sino un ventrílocuo de los numerosos discursos que pueblan el presente y el pasado liberalista venezolano, y en especial de uno de sus más notables propulsores, Arturo Uslar Pietri, cuyo artículo «Sembrar el petróleo», publicado el año 1936, en el Diario Ahora, es emblemático y se repite casi a diario en Venezuela en estos días de hiperpolarización política. Hay en esa polifonía una coincidencia: la preocupación por una supuesta entropía, vista como natural en la sociedad venezolana; ideas que no se divorcian para nada de las que en los años 20 exponían Ignacio Arcaya y Vallenilla Lanz, nuestros ensayistas del Positivismo.

En el telón de fondo de la novela, gravita el rechazo al mesianismo militar. Ordóñez encomia en Escalante el deseo de «crear instituciones fuertes y autónomas, que frenara esa tendencia, tan nuestra, (el subrayado es nuestro) de hacer lo que nos vengan en gana» (121). Insistimos que más que ideas de Escalante, parecieran ideas del autor. Y enfatizamos que en ese «tan nuestra» se deja ver una visión un poco maniquea: ¿de qué tendencia habla? ¿La que describen los positivistas de nuestras razas? No se conocen textos ni discursos en los que el personaje histórico dejara registro de esas ideas. El 
autor (no el narrador) está intentando hacer una narrativa de tesis: se trata de culpar al mesianismo militarista de todos los males nacionales. $\mathrm{Y}$ en ese afán, se vuelve prisionero del famoso síndrome de La Nariz de Cleopatra, al poner en la voz de Ordóñez estas palabras: "Cuando veo lo que ha acontecido aquí desde 1945 es cuando más me convenzo de que el descalabro del doctor Escalante fue un gran infortunio para Venezuela» (121).

Si Escalante hubiese sido presidente de Venezuela, entonces nos hubiéramos evitado los cuatro golpes subsiguientes y los gobiernos dictatoriales de Carlos Delgado Chalbaud y de Marcos Pérez Jiménez. Por eso el fracaso de ese personaje de la política venezolana, fue el fracaso de toda Venezuela. Por esa vía estaríamos rechazando un mesianismo (militar), alabando otro (civil). La historia sería, en esa visión, la urdimbre de los azares. Toda se reduce a «que el militarismo representaba la gran dificultad a vencer por quienquiera que fuese a ocupar la Presidencia». Se da por sentado que sin la locura de Escalante esos avatares serían conjurados.

En la misma tendencia a reivindicar a ciertos dictadores haciéndolos simpáticos, se teje también algunos tópicos que refuerza un lugar común que puso a correr en el imaginario nacional el positivismo: Juan Vicente Gómez duró 27 años en el poder gracias a sus «inteligencia natural», y a que «no tenía una visión heroica de sí mismo» (141). Los contextos históricos se eliden; lo novelesco quiere urdir la idea de que la grandeza de Gómez fue que no quiso parecerse a un militar: «Conocía muy bien al género humano y estaba plenamente consciente de cuáles eran sus propias debilidades y fortalezas» (141). He aquí la bandera del horror a lo entrópico enarbolándose.

En Sumario Federico Vegas trabaja con un evento: el asesinato de Carlos Delgado Chalbaud; y más que ese crimen, se interesa en reflexionar en cómo hizo la historia para ensombrecerlo, a pesar de la cantidad de datos y documentos que circularon sobre el caso. Es importante esbozar algunos elementos biográficos del personaje que focaliza el interés de esta novela: Carlos Delgado Chalbaud, hijo de otro personaje también novelado por Vegas, Román Delgado Chalbaud (véase Falke 2005), quien ve morir a su padre en una invasión destinada a deponer el gobierno de Juan Vicente Gómez en 1929. Luego del fallido intento de golpe, regresa a París, donde se forma como ingeniero. Luego de la muerte del acérrimo enemigo de su padre, el dictador Juan Vicente Gómez, el presidente que lo sustituye, Eleazar López Contreras lo invita a que se incorpore al ejército de Venezuela. Ya como militar logra obtener importantes posiciones en el ejército. Participa junto a civiles ligados a Acción Democrática en el golpe de estado que 
depone al presidente Isaías Medina Angarita. Luego de ser electo como presidente democrático el novelista Rómulo Gallegos es nombrado Ministro de la Defensa. En esa condición lidera el golpe de Estado que depone al mismo Gallegos, presidiendo desde 1948 la Junta Militar de Gobierno, al lado de Marcos Pérez Jiménez y Felipe Llovera Páez. El 13 de noviembre de 1950 es secuestrado y asesinado, por un grupo de hombres a cuya cabeza estaba Rafael Urbina.

Vegas sostiene que esta novela se puede calificar como «hiperhistórica». Afirma que más del cincuenta por ciento de los hechos provienen de la edición del expediente que se hizo con motivo del asesinato de Delgado Chalbaud, cuyo título es también Sumario, publicado por el dictador Pérez Jiménez. En el más ortodoxo esquema de la novela histórica, Vegas yuxtapone personajes ficcionales (Francisco Rueda, su familia, el juez y el periodista) a personajes reales. Los testimonios de estos últimos son tomados literalmente del expediente nombrado. La hiperhistorizada novela abunda en detalles; como el mismo autor lo señala, en una sobre exposición de los hechos. Allí reside, precisamente, la idea del fracaso de la novela: en sobreabundar datos, para dejarnos al final en medio de incertidumbres. De manera que no es del fracaso del personaje central de la novela, Carlos Delgado Chalbaud, de lo que quiere hablar Vegas, sino del verdadero fracaso de la verdad histórica, que aunque la buscan un periodista, un juez, un secretario y una arquitecto (Emilia, hija de Rueda) trocada en sabueso policial, termina totalmente desfigurada.

Esta novela se narra en primera persona. Francisco Rueda siente que la historia se le mete en su casa. El hombre caído (Delgado Chalbaud) es amigo de su padre. Su muerte interrumpe la operación de Alesia, hermana del narrador, porque los médicos que debían atenderla tienen que afrontar la emergencia que implicaba el asesinato del presidente de la Junta Militar. Ese 13 de noviembre de 1950, esa fallida operación coincidió con el único magnicidio que ha tenido Venezuela. Así, pues, la historia gruesa se entrevera con la intrahistoria de la familia Rueda.

Luego de cincuenta años, Francisco Rueda, acicateado por su hija, Emilia, decide hacerse hermeneuta de un evento del que él fue testigo. Como secretario del tribunal, le tocó escribir el expediente; ahora mira su escritura desde un espacio impersonal, procurando entender qué motivos y por qué ocurrió el magnicidio. En los relatos de la novela se despliega una poliédrica complejidad. Por ella discurrirán varios conflictos: el de Rafael Urbina, el autor intelectual de asesinato, a quien mata la policía alegando razones 
poco convincentes; y el retrato de su esposa y numerosos hijos, que fueron estigmatizados cruelmente. También es de destacar la misma tragedia de la viuda de Chalbaud, a quien se le presenta como una mujer sensible, muy vinculada a las artes, $y$ frente a la cual el gobierno de Pérez Jiménez tiene una displicente actitud. Alejandro Teurel afirma que en dicha novela:

La atmósfera tiene mucho de tragedia shakesperiana como apunta el propio juez de la causa, pero también tiene mucho de espesa tragedia griega, donde la multiplicidad de voces del coro comenta y lamenta las acciones de un desdichado, indeciso y desubicado Hamlet criollo.

En el juego shakesperiano, más estético que historicista, Vegas pone al hijo Carlos frente a su padre Román. Hamlet hijo busca a Hamlet padre: el poder negado a éste, le ha sobrado a su descendiente. Al ejercerlo, no deja sentir alguna pena por el fracaso del hombre que arriesgó todo, incluso el bienestar de su familia, por vengar la afrenta del dictador Gómez. Pero diríamos que también estamos frente a un Macbeth víctima del poder, derrotado por su soledad más que por sus amigos militares. Una soledad devenida de la incomprensión de sus compatriotas; la misma incomprensión de la que fue víctima también el embajador enloquecido Escalante que nos describe Francisco Suniaga.

La novela surge de una depresión. Francisco Rueda, ya octogenario, siente que le invade un vacío. Y su hija, Emilia, le impele a llenarlo con la escritura de una novela sobre el asesinato de Carlos Delgado Chalbaud. No es gratuita la imagen: el hermeneuta quiere interpretar lo que hace cincuenta años escribió. Cuando era secretario del tribunal instructor del expediente, era «Hombre de ojos secos». Quizás eso le impedía ver lo que escribía cuando era joven escribiente. Ahora intima con las hijas de Rafael Urbina; ve venir el año 1998 (el año en que ganó las elecciones Hugo Chávez Frías). Tal vez necesita saber qué pasó en el 50 para procurar comprender su presente.

Federico Vegas sostiene que «Como en toda obra literaria, lo importante no es la solución del acertijo sino el significado del acertijo». Buena definición de lo que es la novela: una narración sobre el indagar sin apuros por obtener certezas. No podía escapar esta novela a la crítica implícita al mesianismo militarista, y una inclinación por el Mesías Civil. Así como Suniaga encomia a Diógenes Escalante como el héroe civil caído, Vegas va construyendo con su relato de Delgado una imagen desmilitarizada. Interesantes los pasajes en lo que piensa construyendo puentes en París, y luego haciéndose militar más por las circunstancias que por vocación. En contraste, el verdadero Militar, el forjado para eso, Marcos Pérez Jiménez es calificado categóricamente por 
su hija Emilia como «un Bobo». Vegas quiere condonarle a Chalbaud los dos golpes en los que estuvo involucrado; su participación (su traición a Gallegos, de quien decía tener grandes deudas afectivas) en tales eventos fue producto de un medio político venezolano aún nostálgico de Juan Vicente Gómez.

Las dos novelas en cuestión tematizan el fracaso desde dos perspectivas:

1. Consideran que la historia es una empresa inviable para abordar los eventos históricos que narran. A pesar de la abundancia de datos, de la polifonía que hace patente los hechos, no hay certezas. Los hechos más que configurarse, se desconfiguran en una laberíntica madeja de versiones. Allí parecen coincidir con las prácticas deconstruccionistas derridianas: la realidad no se deja atrapar por significados absolutos.

2. La otra idea del fracaso conlleva la adscripción a un tópico que estereotipa la historia venezolana. Se hace al amparo del ya citado síndrome de La Nariz de Cleopatra y de cierta visión positivista, quizás determinista: el país tiene una tendencia natural a la entropía social; su propensión al caos es el producto de que en la dirección de su Estado predominó (y según su moraleja implícita aún predomina, con el Chavismo) el Mesías Militarista. Las dos novelas relatan cómo el país perdió la oportunidad, bajo el aura de un Mesías Civil, de romper con esa tradición entrópica.

No se podría obviar las analogías existentes entre los dos personajes históricos a los que Vegas y Suniaga recurren, Diógenes Escalante y Carlos Delgado Chalbaud: ambos con formación europea, graduados en Francia e Inglaterra, extranjeros en su propia patria, a los que se les califica de incomprendidos por sus contemporáneos. En ningún momento estos autores se preguntan si la comprensión debe ser bilateral. ¿Comprendieron ellos a la Venezuela pretérita y a la emergente?

Pero ninguna nación fracasa. Fracasan sus utopías. Un país es la suma de creaciones, impulsadas por telos que fracasan o que triunfan. Alguien gana, cuando uno de esos proyectos gana; pero también otros pierden. El poder que hace posible esos proyectos tiene una materialidad ideológica.

Esas novelas proyectan el hombre al que «le corresponde la posibilidad de caer». Y ese hombre náusico, enfrentado a la muerte o a la locura no es sino el ser que apuesta a vivir atrapado en su doble destino de hombre político y de ser la manteca del sacrificio, el mismo rol que James Joyce le atribuía al artista contemporáneo. 


\section{Bibliografía}

Bombsite, 2009, Entrevista a Francisco Suniaga y Federico Vegas, en Bomsite, http:// bombsite.com/issues/999/articles/3380\#.

Centeno, Daniel, 16 al 26 de diciembre de 2009, «¿Boom en Venezuela?», Revista Arcadia, No 51, p. 28-29.

Even-Zohar, Itmar, Spring 1980, «Constraint on realeme insertability in narrative», Poetics Today 1:3, p. 30-34.

Goldmann, Lucien, 1971, Sociología de la Creación Literaria, Buenos Aires, Ediciones Nueva Visión.

Howe, Irwing, 1957, Politics and the novel, New York, Horizon Press.

Lukács, George, 1971, La novela histórica, México, Era.

Medina, Celso, 2004, «De la novela de la idea a la novela carnavalesca», en Carlos Pacheco, Luis Barrera Linares y Beatriz González Estephan (Editores), Nación y Literatura: Itinerarios de la palabra escrita en la cultura venezolana, Caracas, Fundación Bigot, p. 751-761.

Medina, Celso, 2005, Historia y novela en Denzil Romero, Barcelona, Fondo del Caribe.

Pardo, José Luis, 1996, La intimidad, Valencia, Pre-textos.

Ricœur, Paul, 1996, Tiempo y narración, III, El tiempo narrado, México, Siglo XXI.

Suniaga, Francisco, 2008, El pasajero de Truman, Caracas, Random House Mondadori.

Teruel, Alejandro, August 17 de 2010, «La novela de una investigación judicial hasta sus primeras consecuencias...», (Caracas,Venezuela):

http://www.amazon.com/Sumario-Federico-Vegas/dp/9801502924.

Vegas, Federico, 2010, Sumario, Caracas, Alfaguara. 